\title{
PENGEMBANGAN ALAT PERAGA LISTRIK DINAMIS (APLD) BERBASIS INKUIRI UNTUK MENINGKATKAN PENGUASAAN KONSEP SISWA
}

\author{
Muhammad Azhari Hasbi ${ }^{1}$, Kosim $^{2}$, Gunawan $^{2}$ \\ Program Studi Magister Pendidikan IPA Program Pascasarjana Universitas Mataram ${ }^{123}$ \\ azhari_smp1@yahoo.co.id, kosimho@yahoo.com,
}

\begin{abstract}
In this study has been developed a teaching aid of dynamic electricity(APLD) inquiry based to support dynamic electricity of learning. This study included research development. The purpose of this study was to develop and test the effectiveness of the teaching aid to increase mastery of concepts of students. The study involved IX grade of junior students who were following the dynamic electricity of learning were divided into two groups, namely the experimental group and the control group. The instrument used was the dynamic electric concept mastery test. Analysis of data using different test and the average normalized gain scores. This study showed an increase in mastery of concepts in both groups. The Increase concepts mastery of students using APLDinquiry-based was higher than students who studied the electrical KIT with verification based-guide. The increase was highest in the mastery of concept Ohm's Law (69.3\%) and the lowest was in the electric power concept $(10.8 \%)$
\end{abstract}

Keyword: Teaching aid of dynamic electricity (APLD) inquiry based, mastery of concepts dynamic electricity.

\begin{abstract}
ABSTRAK
Dalam penelitian ini telah dikembangkan alat peraga listrik dinamis berbasis inkuiri untuk mendukung pembelajaran listrik dinamis di tingkat SMP.Penelitian ini termasuk penelitian pengembangan.Tujuan dari penelitian ini adalah untuk menghasilkan produk dan menguji efektifitas produk terhadap peningkatan penguasaan konsep siswa.Penelitian ini melibatkan siswa kelas IX SMP yang sedang mengikuti pembelajaran listrik dinamis, yang dibagi menjadi dua kelompok yaitu kelas eksperimen dan kelas kontrol.Instrumen yang digunakan adalah tes penguasaan konsep listrik dinamis. Analisis data menggunakan uji beda rata-rata dan skor gain yang dinormalisasi. Penelitian ini menunjukkan adanya peningkatan penguasaan konsep pada kedua kelas.Peningkatan penguasaan konsep listrik dinamis pada kelas eksperimen yang memperoleh pembelajaran dengan menggunakan APLD berbasis inkuiri lebih tinggi dibandingkan dengan kelas kontrol yang memperoleh pembelajaran dengan menggunakan KIT listrik dan magnet dengan panduan berbasis verifikasi. Peningkatan penguasaan konsep tertinggi terjadi pada konsep Hukum Ohm $(69,3 \%)$ dan terendah pada konsep daya listrik $(10,8 \%)$.
\end{abstract}

Kata kunci : Alat peraga listrik dinamis, panduan praktikum berbasis inkuiri, penguasaan konsep listrik dinamis 


\section{Pendahuluan}

Paradigma baru dalam pembelajaran IPA adalah pembelajaran dimana siswa tidak hanya mempelajari konsep-konsep dan prinsip-prinsip IPA secara verbalitas, pengenalan rumus-rumus dan pengenalan istilah-istilah melalui latihan verbal, namun hendaknya pembelajaran sains lebih banyak memberikan pengalaman belajar melalui proses penemuan serta melatih siswa untuk dapat menerapkan pengetahuannya dalam kehidupannya sehari-hari

Sebagai ilmu yang bersifat empirik penanaman konsep-konsep sains melalui proses inkuiri dapat dilakukan melalui kegiatan praktikum. Kegiatan praktikum memungkinkan siswa untuk melakukan penyelidikan melalui kerja ilmiah (doing science) sehingga dapat menemukan konsep-konsep sains sekaligus dapat mengembangkan sikap kritis siswa. Kerja ilmiah (doing science) secara umum mencakup lima langkah antara lain: (1) mengamati gejala yang ada (eksplorasi pustaka); (2) mengajukan pertanyaan mengapa gejala itu terjadi (merumuskan masalah); (3) membuat hipotesis untuk menjawab persoalan yang diajukan atau menjelaskan alasannya; (4) merencanakan suatu eksperimen dan melakukan eksperimen untuk menguji hipotesis (5) menarik kesimpulan apakah hipotesis benar atau tidak berdasarkan eksperimen yang dilakukan (Suparno, 2006).

Permasalahan yang sering muncul ketika akan melaksanakan inkuiri melalui kegiatan praktikum IPA di sekolah-sekolah adalah tidak tersedianya sarana prasarana yang memadai, terlebih lagi untuk menunjang praktikum fisika. Dari observasi awal yang dilakukan pada beberapa SMP Negeri di Kabupaten Lombok Timur, diperoleh data kondisi alat-alat untuk praktikum fisika yang standar seperti KIT (Kotak Instrumen Terpadu) sangat tidak memadai.Kondisi ini menyebabkan frekuensi kegiatan praktikum di sekolah-sekolah tersebut menjadi sangat kurang dan berujung pada rendahnya hasil belajar IPA di sekolah tersebut.

Selain kurangnya alat-alat praktikum di sekolah-sekolah, faktor lain yang menyebabkan sulitnya pelaksanaan inkuiri siswa melalui kegiatan praktikum adalah panduan praktikum yang ada cendrung hanya bersifat verifikatif. Siswa tidak diajak untuk melakukan proses penemuan dalam kegiatan praktikum sehingga kegiatan praktikum yang dikerjakan siswa menjadi kurang bermakna.

Berdasarkan uraian tersebut, diperlukan sebuah inovasi dalam pembelajaran fisika terutama dalam kegiatan praktikum. Kegiatan praktikum yang perlu 
dikembangkan adalah kegiatan praktikum yang memungkinkan siswa menemukan sendiri konsep-konsep yang dipelajari melalui proses penemuan. Untuk menunjang kegiatan praktikum yang dimaksud perlu diadakan pengembangan baik pada alat-alat praktikum maupun panduan praktikumnya. Untuk itu, pada penelitian ini akan dilakukan pengembangan pada alat-alat untuk menunjang peraktikum khususnya fisika dan panduan praktikum yang berbasis inkuiri.

Mengingat luasnya konsep-konsep fisika yang akan dikuasai siswa, maka penelitian ini difokuskan pada konsep listrik dinamis. Listrik dinamis merupakan salah satu konsep fisika yang penting dikuasai oleh siswa. Hal ini disebabkan karena konsep ini menjadi dasar untuk beberapa konsep lain seperti kemagnetan, induksi elektromagnetik, dan arus bolak-balik yang akan dipelajari oleh siswa pada tingkat lanjutan. Konsep listrik dinamis juga dapat menjadi bekal pengetahuan bagi siswa dalam kehidupan sehari-hari terutama yang berkaitan dengan penggunaan peralatan yang menggunakan energi listrik.

Selain itu, dari hasil studi pendahuluan ditemukan beberapa permasalahan pembelajaran di sekolah yang perlu diperbaiki diantaranya: Pertama,pembelajaran listrik dinamis disekolah-sekolah masih menggunakan metode ceramah dan terpusat pada guru. Kedua,konsep-konsep listrik dinamis bersifat abstak dan memiliki kompleksitas yang tinggi sehingga memerlukan media dalam menanamkan konsepkonsep tersebut pada siswa.

Ketiga, keberadaan peralatan IPA untuk mendukung praktikum listrik dinamis di sekolah-sekolah yang diobservasi sangat tidak memadai jika dibandingkan dengan kondisi ideal yang diharapkan (Standar pelayanan minimal), bahkan terdapat satu sekolah yang tidak memiliki laboratorium.Selain itu, keberadaan alat-alat praktikum listrik dinamis, lebih sedikit jika dibandingkan dengan peralatan untuk mendukung praktikum konsep lainnya.Keempat, Penguasaan konsep listrik dinamis di sekolah yang diobservasi masih rendah.

\section{Metode}

Penelitian ini termasuk jenis penelitian pengembangan dalam bidang pendidikan (Educational Research and Development).Metode penelitian dan pengembangan (Research and Development) adalah metode penelitian yang digunakan untuk menghasilkan produk tertentu dan menguji keefektifan produk tersebut (Sugiyono, 
2012).Dalam penelitian ini dihasilkan produk APLD berbasis inkuiri beserta panduannya, perangkat pembelajaran pada materi listrik dinamis, tes penguasaan konsep listrik dinamis, dan tes kemampuan berpikir kritis siswa.Pengembangan APLD berbasis inkuiri mengacu pada model pengembangan Borg \&Gall yang dimodifikasi oleh Sukmadinata (2011) menjadi tiga tahapan yaitu tahap pendahuluan, tahap pengembangan dan tahap pengujian.

Pada tahap studi pendahuluan dilakukan studi kepustakaan, studi lapangan dan penyusunan produk awal atau draf model.Studi kepustakaan dilakukan dengan mempelajari konsep-konsep listrik dinamis, teori-teori yang berkaitan dengan kegiatan pembelajaran untuk meningkatkan keterampilan berpikir kritis siswa.Selain itu juga dilakukan pengkajian hasil-hasil penelitian terdahulu yang berkaitan dengan penguasaan konsep siswa.Pada saat studi lapangan dilakukan observasi laboratorium untuk mengetahui media atau alat-alat IPA yang dimiliki sekolah.Pada tahap ini juga dilakukan wawancara dengan beberapa orang guru IPA fisika.

Pada tahap pengembangan dilakukan realisasi produk awal APLD berbasis inkuiri dan perangkat pendukung yang meliputi, silabus, RPP, LKS.Perangkat pembelajaran dan alat peraga yang dihasilkan selanjutnya divalidasi oleh 3 orang ahli.Setelah dilakukan validasi, tahapan selanjutnya adalah melakukan perbaikan berdasarkan masukan dan saran-saran dari ahli.kemudian dilakukan ujicoba terbatas untuk menguji dan menyempurnakan produk.

Ujicoba terbatas dilakukan pada satu sekolah yaitu SMPN 2 Montong Gadingyang melibatkan 36 orang siswa.Hasil ujicoba terbatas dan hasil perbaikan selanjutnya digunakan untuk ujicoba skala luas.Ujicoba skala luas dilakukan pada siswa yang jumlahnya lebih banyak. Ujicoba skala luas dilaksanakan pada dua kelas dari sekolah yang berbeda yaitu SMPN 2 sikur dan SMPN 1 Terara dengan melibatkan 66 orang siswa. Dua sekolah ini dipilih sebagai representasi dari sekolah di daerah perkotaan dan pedesaan.Dari hasil uji coba skala luas dilakukan evaluasi dan penyempurnaan pada alat peraga peraktek yang dihasilkan, sehingga diperoleh produk final.

Produk final yang dihasilkan selanjutnya diuji efektifitasnya melalui inplementasi dalam pembelajaran pada kelas eksperimen dan membandingkannya dengan kelas kontrol yang belajar dengan menggunakan alat peraga praktek yang ada di sekolah yang sering digunakan oleh guru, berupa KIT listrik dan magnet.Tahapan 
pengujian dilaksanakan di SMPN 1 Montong Gading dengan jumlah populasi sebanyak 220 orang yang terdiri dari 6 rombongan belajar.

Jumlah sampel yang digunakan sebanyak 72 orang siswa yang terbagi menjadi dua kelas yaitu kelas eksperimen dan kelas kontrol.Teknik sampling yang digunakan adalah Cluster Random Sampling yaitu pengambilan sampel secara berkelompok dengan penentuan kelompok secara acak.Hal inidilakukan karena berdasarkan uji homogenitas sampel dari data ulangan harian sebelumnya, menunjukkan sampel memiliki distribusi yang homogen pada tiap kelas. Metode yang digunakan adalah metode eksperimen dengan desain pretest-posttest control group design, yaitu dilakukan pretest dan posttestdan dilakukan randomisasi (Setyosari, 2009).

Instrumen yang digunakan adalah tes penguasaan konsep listrik dinamis yang dihubungkan dengan tingkatan kognitif Bloom yang direvisi meliputi aspek $\mathrm{C}_{1}$ sampai $\mathrm{C}_{5}$.Pengolahan data penguasaan konsep diawali dengan melakukan uji normalitas dan uji homogenitas.Uji Normalitas pada penelitian ini menggunakan uji Kolmogorv Smirnov dan uji homogenitas menggunakan Uji Levene.Untuk mengetahui peningkatan penguasaan konsep siswa dilakukan dengan menghitung besarnya skor gain yang dinormalisasi (N-gain). Gain rata-rata ternormalisasi adalah selisih skor rata-rata posttes terhadap skor rata-rata pretes. Penggunaan $\mathrm{N}$-gain ini bertujuan untuk menghindari kesalahan dalam menginterpretasikan prolehan gain masing-masing siswa. Untuk memperoleh skor N-gain digunakan rumus yang dikembangkan oleh Hake (1999) sebagai berikut :

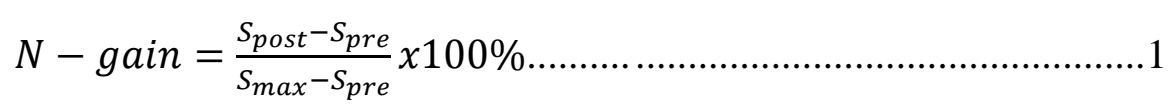

Besarnya faktor-g dikategorikan sebagai berikut: tinggi bila $\mathrm{g}>0.7$, sedang bila $0,3 \leq \mathrm{g} \leq 0,7$, dan rendah bila $\mathrm{g}<0,3$. Pengujian signifkansi efektivitas alat peraga praktek fisika berbasis inkuiri menggunakan t-test berkorelasi. Persamaan yang digunakan adalah :

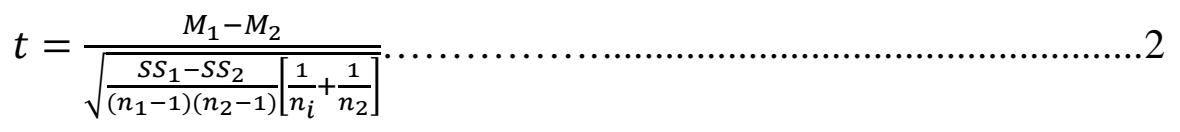

Keterangan

$\mathrm{M}_{1} \quad$ = Rata-rata skor kelompok 1

$\mathrm{M}_{2}$ = Rata-rata skor kelompok 2

$\mathrm{SS}_{1}=$ Sum of Square kelompok 1 


$$
\begin{array}{ll}
\mathrm{SS}_{2} & =\text { Sum of Square kelompok } 2 \\
\mathrm{n}_{1} & =\text { Jumlah subyek kelompok } 1 \\
\mathrm{n}_{2} & =\text { Jumlah subyek kelompok } 2
\end{array}
$$

\section{Hasil dan Pembahasan}

Pada tahap pengujian dilakukan tes awal sebelum pembelajaran.Setelah pembelajaran listrik dinamis pada kelas eksperimen dan kelas kontrol dengan menggunakan media dan pendekatan yang berbeda, selanjutnya dilakukan tes akhir untuk mengetahui penguasaan konsep siswa terhadap materi yang yang sudah disampaikan.Data perolehan skor rata-rata tes awal, tes akhir dan $\mathrm{N}$-gain pada kelas eksperimen dan kelas kontrol secara rinci dapat dilihat pada Tabel 1.

Tabel 1.Deskripsi Skor Tes Penguasaan Konsep Listrik Dinamis Siswa

\begin{tabular}{|c|c|c|c|c|c|c|}
\hline \multirow{2}{*}{ Variabel } & \multicolumn{3}{|c|}{ Kelas Eksperimen (N=36) } & \multicolumn{3}{c|}{ Kelas Kontrol (N=36) } \\
\cline { 2 - 7 } & $\begin{array}{c}\text { Tes } \\
\text { Awal }\end{array}$ & $\begin{array}{c}\text { Tes } \\
\text { Akhir }\end{array}$ & $\%<\mathrm{g}>$ & $\begin{array}{c}\text { Tes } \\
\text { Awal }\end{array}$ & $\begin{array}{c}\text { Tes } \\
\text { Akhir }\end{array}$ & \begin{tabular}{c}
$\%>\mathrm{g}>$ \\
\hline Rata-rata PK
\end{tabular} \\
\hline Standar Deviasi PK & 36.6 & 59.8 & 36.9 & 31.4 & 47.3 & 23.2 \\
\hline
\end{tabular}

Perbandingan rata-rata pencapaian tes awal, tes akhir, dan N-gain antara kelas eksperimen dan kelas kontrol diperlihatkan pada Gambar1

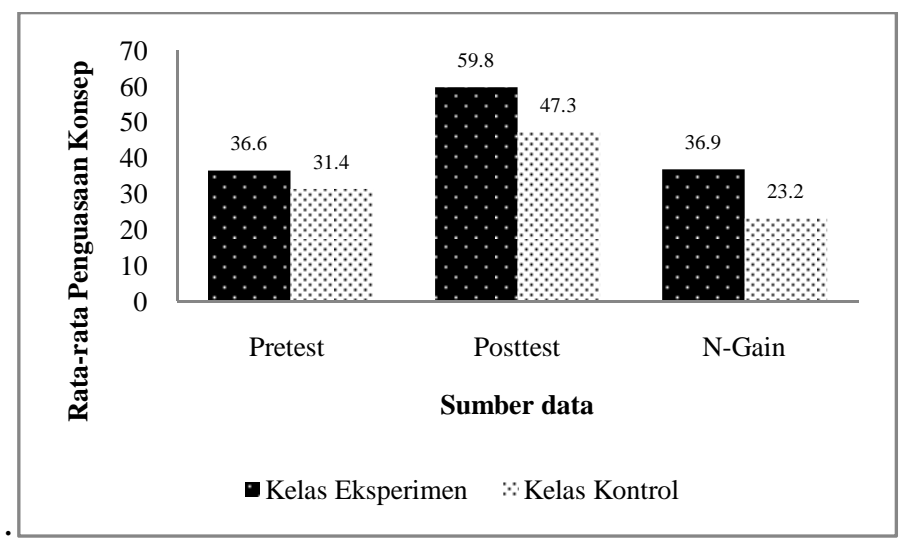

Gambar 1.Perbandingan Skor Rata-rata Tes Awal, Tes Akhir dan N-gain Antara Kelas Eksperien dan Kelas Kontrol.

Hasil analisis secara umum menunjukkan bahwa terdapat peningkatan penguasaan konsep listrik dinamis pada kedua kelas, namun peningkatan penguasaan konsep pada kelas eksperimen lebih tinggi dibandingkan dengan kelas kontrol.Hal ini 
menunjukkan bahwa pembelajaran dengan menggunakan APLD berbasis inkuiri dapat meningkatkan penguasaan konsep siswa pada materi listrik dinamis.Peningkatan penguasaan konsep ini merupakan pengaruh dari penyajian konsep listrik dinamis yang bersifat abstrak ditampilan dalam bentuk konkrit melalui pengamatan dan pengukuran variabel dalam rangkaian percobaan dengan menggunakan APLD berbasis inkuiri. Hal ini senada dengan pendapat Smaldino, et al. (2012) yang menyatakan bahwa pembelajaran yang melibatkan proses rekayasa atau manipulasi objek riil dapat menyediakan pengalaman konkrit yang dapat memperjelas konsep yang dipelajari.

Disamping itu, peningkatan penguasaan konsep pada kelas eksperimen juga merupakan implikasi dari pembelajaran melalui kegiatan praktikum berbasis inkuiri.Tahapan-tahapan inkuiri yang dilaksanakan oleh siswa pada saat melaksankan praktikum memungkinkan siswa untuk menemukan sendiri konsep-konsep listrik dinamis sehingga retensinya lebih lama.Hal ini sesuai dengan pendapat Mayer seperti yang dikutip Eggen \& Kauchak(2012) mengatakan bahwa belajar penemuan cendrung menghasilkan retensi (penyimpanan) dan transper jangka panjang lebih baik dibandingkan dengan mengajar pemaparan.

Meskipun secara umum terdapat perbedaan peningkatan penguasaan konsep yang signifikan antara kelas eksperimen dan kelas kontrol, namun jika ditinjau dari tiap-tiap label konsep, tidak semua label konsep yang dapat ditingkatkan penguasaanya pada siswa ketika belajar dengan menggunakan APLD berbasis inkuiri.Rekapitulasi skor rata-rata penguasaan konsep listrik dinamis pada tiap label konsep secara rinci dapat dilihat pada Tabel 2.

Tabel 2.Rekapitulasi Skor Rata-rata Tes Awal, Tes Akhir, dan N-gain Penguasaan

Konsep pada Tiap Label Konsep

\begin{tabular}{|c|c|c|c|c|c|c|c|c|c|c|c|}
\hline \multirow{3}{*}{ Label Konsep } & \multicolumn{5}{|c|}{ Nilai Kelas Eksperimen } & \multicolumn{5}{|c|}{ Nilai Kelas Kontrol } & \multirow{3}{*}{$\begin{array}{c}\Delta<\mathrm{g}> \\
\%\end{array}$} \\
\hline & \multicolumn{2}{|c|}{ Tes Awal } & \multicolumn{2}{|c|}{ Tes Akhir } & \multirow{2}{*}{$<\mathrm{g}>\%$} & \multicolumn{2}{|c|}{ Tes Awal } & \multicolumn{2}{|c|}{ Tes Akhir } & \multirow{2}{*}{$<\mathrm{g}>\%$} & \\
\hline & $\mathrm{NR}^{*}$ & $\%$ & $\mathrm{NR}^{*}$ & $\%$ & & $\mathrm{NR}^{*}$ & $\%$ & $\mathrm{NR}^{*}$ & $\%$ & & \\
\hline Hukum Ohm & 9.6 & 57.8 & 14.9 & 89.4 & 69.3 & 6.2 & 37.2 & 8.5 & 51.1 & 21.1 & 48.2 \\
\hline Hambatan Kawat & 7.7 & 46.1 & 11.9 & 71.7 & 41.9 & 5.0 & 30.0 & 6.8 & 40.6 & 11.3 & 30.6 \\
\hline Hukum I Kirchoff & 7.3 & 43.9 & 11.1 & 66.7 & 31.9 & 7.1 & 42.8 & 9.4 & 56.6 & 10.9 & 21.0 \\
\hline Rangkaian Hambatan & 4.1 & 24.4 & 5.8 & 35.0 & 12.2 & 3.6 & 21.7 & 8.8 & 52.8 & 38.9 & -26.7 \\
\hline Energi Listrik & 4.5 & 27.2 & 11.3 & 67.7 & 58.9 & 4.6 & 27.8 & 6.6 & 39.4 & 13.2 & 45.7 \\
\hline Daya Listrik & 3.3 & 20.0 & 4.7 & 28.3 & 10.8 & 4.8 & 28.9 & 7.2 & 43.3 & 18.1 & -7.3 \\
\hline
\end{tabular}


Sedangkan perbandingan peningkatan penguasaan konsep listrik dinamis tiap label konsep dapat dilihat pada Gambar 2.

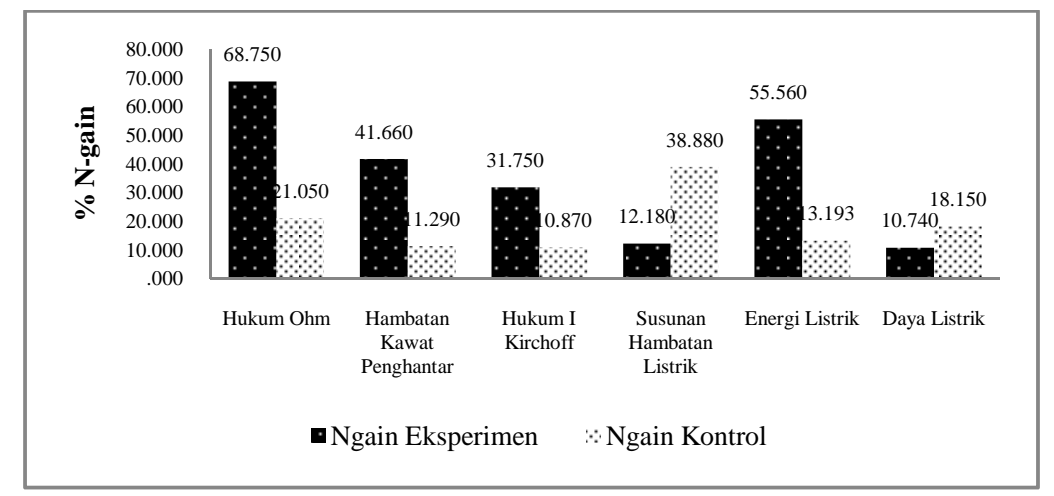

Gambar 2.Perbandingan Peningkatan Penguasaan Konsep Listrik Dinamispada Tiap Label Konsep.

Berdasarkan hasil analisis statistik, APLD berbasis inkuiri berpengaruh signifikan terhadap peningkatan penguasaan konsep pada beberapa materi.Perbedaan peningkatan yang signifikan diantara kedua kelas terjadi pada konsep hukum $\mathrm{Ohm}(\mathrm{Z}$ sebesar -5,150 lebih kecil dari -1,96 dan $\mathrm{P}$ sebesar 0,00 lebih kecil dari 0,05), hambatan kawat ( $\mathrm{Z}$ sebesar -4,078 lebih kecil dari -1,96 dan nilai $\mathrm{P}$ sebesar 0,000 lebih kecil dari 0,05), dan energi listrik ( $Z$ sebesar -6,131 lebih kecil dari -1,96 dan nilai $\mathrm{P}$ sebesar 0,000 lebih kecil dari 0,05),dimana peningkatan penguasaan konsep kelas eksperimen lebih tinggi dari kelas kontrol.

Hal ini dapat dipahami karena tahapan-tahapan praktikum dengan menggunakan APLD berbasis inkuiri dapat mengembangkan kerja ilmiah siswa yang pada gilirannya mendukung penguasaan siswa pada konsep yang diajarkan serta siswa mampu menerapkan pemahamannya dalam situasi yang berbeda.Dengan demikian ketika siswa diberikan suatu permasalahan, penguasaan konsep siswa berpengaruh terhadap kemampuannya memberikan jawaban yang lebih baik dibandingkan dengan kelas kontrol.

Hal yang mengejutkan terjadi pada konsep susunan hambatan listrik, hasil analisis statistik menggunakan Uji Mann Whitney Udiperoleh nilai Z sebesar -3,360 lebih kecil dari -1,96 dan nilai P sebesar 0,000 lebih kecil dari 0,05.Sehingga dapat disimpulkan, rata-rata peningkatan penguasaan konsep pada materi susunan hambatan listrik antara kelas eksperimen dan kelas kontrol berbeda secara signifikan dengan nilai rata-rata kelas kontrol lebih tinggi dari kelas eksperimen. Dengan demikian APLD Berbasis inkuiri tidak berpengaruh secara signifikan terhadap peningkatan 
penguasaan konsep listrik dinamis pada materi rangkaian hambatan listrik.Untuk konsep daya listrikhasil analisis statistik menunjukkan nilai Z sebesar -1,019 lebih besar dari -1,96 dan nilai P sebesar 0,303 lebih besar dari 0,05. Dengan demikian ratarata peningkatan penguasaan konsep antara kelas eksperimen dan kelas kontrol pada materi daya listrik tidak berbeda secara signifikan.

Hasil analisis statistik menunjukkan pada kedua konsep ini peningkatan penguasaan konsep kelas kontrol lebih tinggi dibandingkan dengan kelas eksperimen.Meskipun kelas eksperimen melakukan praktikum melalui tahapan inkuiri, ternyata belum mampu meningkatkan penguasaan konsep siswa pada kedua materi ini.Menurut analisis peneliti rendahnya penguasaan konsep kelas eksperimen dibandingkan dengan kelas kontrol pada kedua materi ini disebabkan oleh beberapa faktor diantaranya berasal dari panduan percobaan dan instrumen tes penguasaan konsep yang diberikan.

Berdasarkan analisis pada panduan percobaan yang dikembangkan, rangkaian susunan hambatan listrik memiliki kelemahan, dimana susunan hambatan seri dan paralel digabung dalam sebuah lembar kerja sehingga alokasi waktu yang tersedia tidak memadai jika dibandingkan dengan banyaknya kegiatan yang dikerjakan siswa. sementara pada kelas kontrol kegiatan praktikum pada konsep rangkaian hambatan listrik dilaksanakan secara terpisah antara rangkaian hambatan seri dan paralel.

Kondisi ini menyebabkan percobaan yang dilakukan oleh siswa pada kelas eksperimen menjadi tidak optimal.Tahapan diskusi kelompok serta presentasi hasil kegiatan setelah kegiatan praktikum selesai tidak dapat dilaksanakan.Hal ini diperkirakan menjadi pemicu sehingga penguasaan konsep siswa pada materi susunan hambatan listrik pada kelas eksperimen lebih rendah dibandingkan dengan kelas kontrol.

Selanjutnya pada konsep daya listrik, rendahnya penguasaan konsep siswa kelas eksperimen dibandingkan dengan kelas kontrol dipengaruhi oleh rendahnya penguasaan konsep siswa pada materi susunan hambatan listrik. Hal ini dapat dipahami karena instrumen penguasaan konsep pada materi daya listrik sebagian besar berisi permasalahan tentang daya suatu alat-alat elektronik yang dirangkai satu sama lain baik secara seri maupun secara paralel, sehingga sebelum menyelesaikan masalah tersebut, siswa harus mengetahui besar hambatan alat terlebih dahulu. Dengan demikian jika penguasaan konsep siswa rendah pada konsep susunan 
hambatan listrik akan mempengaruhi penguasaan konsep siswa pada materi daya listrik.

Demikian halnya pada materi Hukum 1 Kirchoff, meskipun materi ini tidak terlalu kompleks, dimana siswa hanya mengidentifikasi arus yang masuk dan keluar titik percabangan, namun karena soal yang diberikan berkaitan dengan arus pada rangkaian bercabang pada beberapa susunan hambatan, menyebabkan perbedaan penguasaan konsep antara kelas eksperimen dan kelas kontrol tidak berbeda secara signifikan walaupun peningkatan penguasaan konsep kelas eksperimen lebih tinggi dari kelas kontrol.

Beberapa temuan-temuan penelitian yang dijelaskan di atas, sejalan dengan hasil penelitian sebelumnya yang menyebutkan adanya keuntungan bagi siswa yang melakukan praktikum berbasis inkuiri.Muhaimin.A, (2013) mengembangkan media tiga dimensi kapasitor dapat meningkatkan pemahaman konsep kapasitor pada siswa SMK. R. Ariesta, dkk (2011) menemukan bahwa melalui kegiatan laboratorium berbasis inkuiri terbimbing dapat mengembangkan kerja ilmiah yang berdampak pula pada pemahaman konsep dan mampu menerapkannya pada situasi baru. Demikian juga dengan hasil penelitian Wahyudi (2004) menerapkan pembelajaran penemuan pada topik fluida dengan menggunakan LKS secara signifikan meningkatkan retensi penguasaan konsep siswa.

Selain itu keuntungan lain yang diperoleh siswa melalui kegiatan praktikum berbasis inkuiri adalah: (1) memberikan pengaruh terhadap sikap ilmiah siswa, (2) meningkatkan pemahaman siswa tentang hukum-hukum fisika yang berkaitan dengan materi listrik dinamis, (3) meningkatkan pemahaman siswa tentang hubungan antara konsep-konsep fisika pada materi listrik dinamis. Dengan demikian penggunaan APLD berbasis inkuiri pada pembelajaran listrik dinamis dapat meningkatkan penguasaan konsep siswa.

\section{Kesimpulan dan Saran}

Berdasarkan hasil penelitian ini dapat diambil kesimpulan bahwa : (1) APLD berbasis inkuiri yang dikembangkan berpengaruh secara signifikan terhadap peningkatan penguasaan konsep siswa pada beberapa label konsep antara lain: Hukum Ohm, hambatan kawat penghantar, dan energi listrik. (2) APLD berbasis inkuiri yang dikembangkan tidak memberikan pengaruh yang signifikan terhadap penguasaan 
konsep siswa pada beberapa label konsep yaitu: Hukum 1 Kirchoff, susunan hambatan listrik, dan daya listrik.

Untuk memberikan pengalaman langsung pada siswa dalam pembelajaran khususnya dalam kegiatan praktikum, APLD berbasis inkuiri dapat menjadi alternatif media pembelajaran karena terbukti dapat meningkatkan penguasaan konsep listrik dinamis siswa.Pada beberapa bagian APLD berbasis inkuiri perlu mendapat perbaikan agar penggunaannya menjadi optimal dalam meningkatkan penguasaan konsep siswa terutama pada panduan praktikumnya.

\section{Daftar Pustaka}

Ariesta, R., \& Supartono.2011. Pengembangan Perangkat Perkuliahan Kegiatan Laboratorium Fisika Dasar II Berbasis Inkuiri Terbimbing untuk Meningkatkan Kerja Ilmiah Mahasiswa.Jurnal Pendidikan Fisika Indonesia. ISSN: 1693-1264, No. 7, 2011. Hal: 62-68

Eggen,P\& Kauchak, D. 2012.Strategi dan Model Pembelajaran.Satrio Wahono (penerjemah). 2012. Jakarta: PT Indeks

Hake, R.R., (1999).Analyzing Change / Gain Scores, diakses tanggal 10 Maret 2013dari http://www.physics.indiana.edu/ sdi/AnalyzingChange-Gain.pdf.

Heinich, R., Moelenda, M., Smaldino, S.E., \& Russel, J.D. 2002.Instructional Technology and Media for Learning. Ohio: Pearson

Muhaimin, A, 2013.Pengembangan Media Tiga Dimensi Kapasitor (MTDK) dan Pengaruhnya terhadap Pemahaman Konsep, Sikap Ilmiah, dan Keterampilan Proses Sains Ditinjau dari Gaya Belajar Siswa SMK.Tesis Magister Pendidikan IPA Universitas Mataram.Tidak diterbitkan.

Setyosari, P. 2012. Metode penelitian pendidikan dan pengembangan. Jakarta: Kencana.

Smaldino, E.E., Lowther, D.L., \& Russel, J.D. 2011.Teknologi Pembelajaran dan Media untuk Belajar. Arif Rahman (penerjemah). 2012. Jakarta: Kencana

Sugiono .2012.Metode Penelitian Pendidikan. Bandung: Alfa Beta

Sukmadinata, N.S. 2011. Metode Penelitian Pendidikan. Bandung: Penerbit Rosdakarya

Suparno, P. 2006. Metodologi Pembelajaran Fisika Konstruktifistik dan Menyenangkan. Jogjakarta: Universitas Sanata Dharma.

Wahyudi.2004. Pembelajaran Fisika tentang Fluida Bergerak Melalui Proses Penemuan Pada Siswa SMA Kelas IX. Tesis Magister Pendidikan Sains UPI Bandung: Tidak diterbitkan. 